\title{
Investigating Students' Perceptions on Mobile Learning Services
}

\author{
http://dx.doi.org/10.3991/ijim.v8i4.3965 \\ Mohammed Amin Almaiah, Masita @ Masila Abdul Jalil \\ University Malaysia Terengganu, Terengganu, Malaysia
}

\begin{abstract}
M-learning is a form of learning, which has similarities and differences with the electronic learning (elearning). It is mainly based on the use of the mobile wireless technologies that allow for learners to easily access learning materials anytime he desires and anywhere, whether on campus or off campus. Therefore, this creates a new flexible learning environment in the context of different learning settings. Students' perception of such technology is one of the most important factors for successful adoption of m-learning in the higher education environment. This study is conducted to investigate the perceptions of students in University Malaysia Terengganu (UMT) to move towards applying m-learning in their studies by using their mobile devices and to explore their expectations on mobile learning services. A total number of 91 undergraduate students majoring in computer science participated in the study. The findings show that the students have positive perception towards mobile learning and would like to use their mobile devices for both learning and administrative services.
\end{abstract}

Index Terms-Mobile learning (M-learning), Electronic learning (E-learning), mobile wireless, students' perceptions.

\section{INTRODUCTION}

The uses of mobile devices and related technologies have increased significantly in the recent years because of their capabilities to be used in many fields. The use of devices such as mobile phones, smart phones and PDA have found their way into the learning and educational sector as well. In addition, students and teachers in the universities and education institutions around the world are increasingly using the mobile technology to access learning materials, internet access and facilitate learning in new and innovative ways [19]. M-learning is the next form of e-learning that support learning anywhere and anytime which depends on communication technologies such as GSM, WAP, GPRS and Bluetooth. Over the past few years the number of studies has increased for the adoption of m-learning in many countries such as USA, Asia, Britain, Scandinavia, and Australia [3]. University of Florida supports the idea of using m-learning through providing access to fast wireless network using mobile devices on campus [6]. Thus, the utilization of $\mathrm{m}$ Learning technology offers benefits to both students and educational institutions involved $[10\rceil$. In addition, Pointed out that more focus should be directed towards the importance of m-learning and its uses among universities students because it provides many of services at any time, any place. Therefore, the higher education institutions must plan in future to provide a more flexible learning environment to meet the needs of new generations of students who are increasingly attracted towards mobile technology.

Despite there are many studies have been conducted to investigate the use of m-learning in higher education institutions, but it is still limited. However, the rate of adoption of the higher education institutions for the use of $\mathrm{m}$ learning is still slow; this means that even though it has many advantages, there are many obstacles that limit their acceptance within the higher education environment $[1]$. One of the main reasons that are attributed to the poor usage of m-learning technology is the lack of sufficient studies that explore the factors that influence m-learning acceptance in the higher education institutions [22]. Therefore, this study is conducted to investigate the students' perceptions and expectations on m-learning services in the higher education institutions.

\section{PROBLEM STATEMENT}

The popularity of mobile devices is increasing significantly day by day, as many learners are using mobile technology in their learning environment [16]. M-learning has many features such as flexibility of learning anytime and anywhere which have brought new changes in learning and education environment. Therefore, this feature enables students to take advantage of their free time while they are outside the classroom to complete their study and homework [24]. In addition, students who are waiting for their flight at the airport, they can use wireless mobile devices such as smart phone, PDA and Tablet PC to access lecture materials or download an assignment or interact with their instructors or friends.

Despite m-learning has been developed fast, there is need to investigate the elements that have influence mlearning acceptance among students in higher education institutions [14, 21]. Without considering the importance of m-learning acceptance among students and explore students' readiness levels to use mobile learning can cause ineffective use of $\mathrm{m}$ - learning devices. Therefore, study of the perceptions of students for using m-learning may help the success of the adoption of m-learning in higher education environment. Chen et al. [7] pointed out that a better understanding of the students' requirements will help the decision maker to adopt m-learning successfully.

Few empirical research studies on the use of m- learning in higher education institutions have been reported [39]. Some of these studies have suggested some of the factors that influence m-learning acceptance in higher education institutions. However, there is still gap in the field of m-learning adoption; where many researchers have called for further investigation and research in the field of adoption of m-learning in higher education institu- 
tions $[21,11,14,15]$. Further research is required to investigate the students' perceptions of the application of mobile devices and m-learning services in higher education institutions. Hence, the study here, aims to explore the students' perceptions of the application of m-learning services in higher education environments.

\section{RELATED WORKS}

Several of studies have conducted the adoption of $\mathrm{m}$ learning in many countries such as USA, Britain, Scandinavia, and Australia [1]. Andrew and others [3] discussed groups of directions in an effort to investigate the use of the m-learning in the higher education including: fostering interactivity on-campus using mobile devices, investigation the needs of students and strategies for low-cost mlearning use.

Pointed out that more focus should be directed towards the importance of m-learning and its usage among students in universities because it provides many of the services at any time and any place. Korucu and Alkan studied the relation and differences between m-learning and elearning and the use of m-learning in the higher education in turkey. The results showed that the use of m-learning technologies has become of the most important technologies that support learning because it offers learning any time, any place. In addition, m-learning will contribute greatly to the improvement of teaching and learning in the future. Another study conducted by Haag [9], focused on m-learning delivery courses to provide the students with an alternative platform to continue their learning after leaving the classroom. The findings showed that seventy percent of the participants preferred m-learning courses version more than e-learning courses.

In addition, yusup discussed the status of iPad used as a device for learning among primary school teachers in Malaysia. A survey was conducted in which 93 teachers participated. The teachers were provided with iPads to help them in the program of online distance-learning. The results indicated that the majority of teachers' prefered to use iPad as compared to laptops during the teaching and learning process and trust that iPad is a very important learning device to share information among colleagues.

\section{M-LEARNING Vs. E-LEARNING}

Despite E-learning and M-learning have similar elements, but there are some differences in terms of technology, learner access and mode of communication. TABLE (1) compares the aspects of E-learning and M-learning which were derived from a literature review of M-learning $[4,13,17]$.

\section{M-LEARNING SERVICES FOR HIGHER EDUCATION INSTITUTIONS:}

M-learning is considered to be the next step of elearning by the use of wireless mobile devices and other communication technologies to enable instructors and learners to conduct learning process anytime and anyplace. There are two main services that m-learning offered which are: (1) learning materials services such as content materials (2) administrative services such as registration and schedule students as shown Figure 1.

Several M-learning studies in higher education institutions examined the manner in which wireless mobile devices are implemented in teaching and learning methods
TABLE I.

"COMPARISON BETWEEN E-LEARNING AND M-LEARNING"

\begin{tabular}{|l|l|l|}
\hline \multicolumn{1}{|c|}{ Features } & \multicolumn{1}{|c|}{ E-learning } & \multicolumn{1}{c|}{ M-learning } \\
\hline protocol & Web-Based & WAP-Based \\
\hline Network & Wired & Wireless \\
\hline Accessibility & Anywhere & $\begin{array}{l}\text { Anywhere and Any- } \\
\text { time }\end{array}$ \\
\hline Connectivity & Intranet or Internet & $\begin{array}{l}\text { Mobile Networks, } \\
\text { GSM, } \\
\text { GPRS, UMTS and } \\
\text { CDMA. }\end{array}$ \\
\hline $\begin{array}{l}\text { Devices } \\
\text { Instructor to } \\
\begin{array}{l}\text { Student commu- } \\
\text { nication }\end{array}\end{array}$ & $\begin{array}{l}\text { Asynchronous } \\
\text { Delayed Communica- } \\
\text { tion }\end{array}$ & $\begin{array}{l}\text { Mobile Phone, } \\
\text { Smart Phone } \\
\text { and PDA }\end{array}$ \\
\hline
\end{tabular}

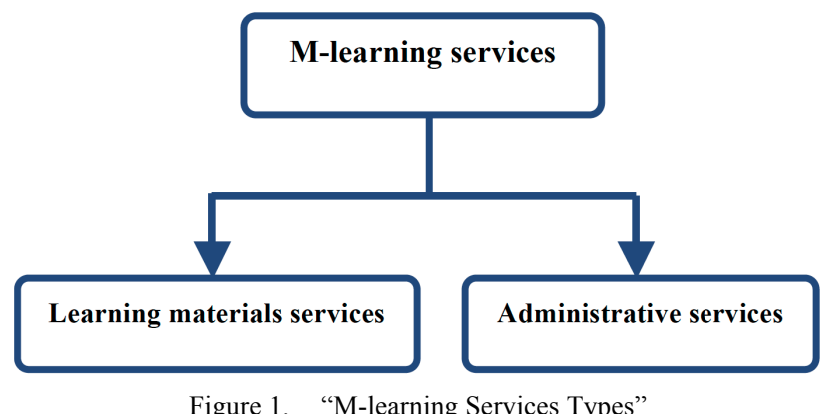

of various universities. Alzaza and Yaakub [2] conducted a study to investigate the importance of the use of $\mathrm{m}$ learning services among Malaysian higher education students. The results showed that the courses registration and result exams are the highest rank and followed by library services, schedule services, and admission services.

Botzer and Yerushalmy [5] conducted a project to investigate the relevance of cellular application called "math4mobile". Researchers used this project "math4mobile" to understand the opportunity of adopting personal and mobile technologies for learning functions, particularly the benefit of mobile phones for facilitating mathematical learning. The project contained group effort activities such as making use of cellular video camera to capture certain images, making use of MMS (multimedia message) for sharing video clips among the participants, making use of mathematical applets to create graphs which provide representation of information and making use of SMS (short message system) to send and exchange verbal messages and mathematical objects. The study found that the positive engagement of the students in the project and these devices able to enhance the learning process.

\section{Methodology}

A questionnaire was designed to investigate the perceptions of the students towards applying m-learning. The instrument was adapted from Trifonova, Georieva and Ronchetti which contains four sections. The first section contains general information to collect data about users' demographic such as gender, age and year of study. The second section contains multiple choice questions to find 
out about the availability of mobile devices, accessing the internet by mobile devices and students' knowledge and experience with mobile technology media. In the third section, there are developed 11 statements with a fivepoint Likert scale ranged from 1-Strongly Disagree to 5Strongly Agree designed to explore the students' perceptions towards applying m-learning. Finally, the fourth section based on the scales 1 to 3 where 1-Useful, 2Neutral and 3-Not Useful to explore the students' expectations on m-learning services.

The questionnaire was distributed to the first, second and third year Computer Science students, School of Informatics and Applied Mathematics, University Malaysia Terengganu (UMT). A total number of 100 responses were obtained. Nine questionnaires were discarded due to being incomplete answers.

\section{DATA ANALYSIS AND RESULTS}

\section{A. Respondents profile}

As shown in Table II, $50.5 \%$ of the respondents were male and 49.5 were female. The majority of respondents $81.3 \%$ were aged between $18-22$ years while $22-26$ years were $18.7 \%$. In terms of year of study, most of the respondents $38.5 \%$ were the second year followed by first year $35.2 \%$ and then third year $26.4 \%$. This indicates that the results represent perceptions and expectations of different levels of students.

\section{B. Availability of Mobile Devices}

As shown in Figure 2 the results indicate that the majority of respondents $68.1 \%$ have smartphone, $18.7 \%$ of respondents have mobile phone, while $11.0 \%$ have tablet Pc and $1.1 \%$ have PDA and other devices.

\section{Students' Knowledge and experience of Mobile Technology and M-learning}

The study found that the respondents were familiar with mobile technology. The questions 1-3 asked respondents if they access internet using their mobile device. As shown in Figure 3 the results showed that $89 \%$ of the respondents accessed the internet using their mobile device.

In addition, $81 \%$ of respondents used their mobile device to access the internet on a daily basis as shown in Figure 4.

Furthermore, the results showed that $68.1 \%$ of the respondents were paying money to access the Internet using their mobile devices; this indicates normal price of accessing the internet using mobile devices. Question 4 asked respondents if they used mobile device to learn computer science. The results showed $52.7 \%$ of respondents used their mobile devices to learn computer science and $41.8 \%$ did not.

The last two questions 5-6 asked respondents if they have heard about m-learning and their opinions of $\mathrm{m}$ learning. The results indicated that $58.2 \%$ of respondents knew about mobile learning and 41.8 did not. The majority of respondents $82.4 \%$ answered that m-learning is good idea and would like to use it, while $9.9 \%$ answered good idea but I would not like to use it, whereas $1.1 \%$ don't think it is good idea, and $6.6 \%$ answered others as shown in Figure 5.
TABLE II.

"RESPONDENTS PROFILE"

\begin{tabular}{|c|c|c|c|c|}
\hline & Classification & Frequency & percent & $\begin{array}{c}\text { cumulative } \\
\text { percent }\end{array}$ \\
\hline \multirow{2}{*}{ Gender } & Male & 46 & 50.5 & 50.5 \\
\cline { 2 - 5 } & Female & 45 & 49.5 & 100.0 \\
\hline \multirow{2}{*}{ Age } & $18-22$ & 47 & 81.3 & 81.3 \\
\cline { 2 - 5 } & $22-26$ & 17 & 18.7 & 100.0 \\
\hline \multirow{2}{*}{$\begin{array}{c}\text { Year of } \\
\text { study }\end{array}$} & $1^{\text {st }}$ & 32 & 35.2 & 35.2 \\
\cline { 2 - 5 } & $2^{\text {nd }}$ & 35 & 38.5 & 73.6 \\
\cline { 2 - 5 } & $3^{\text {rd }}$ & 24 & 26.4 & 100.0 \\
\hline
\end{tabular}

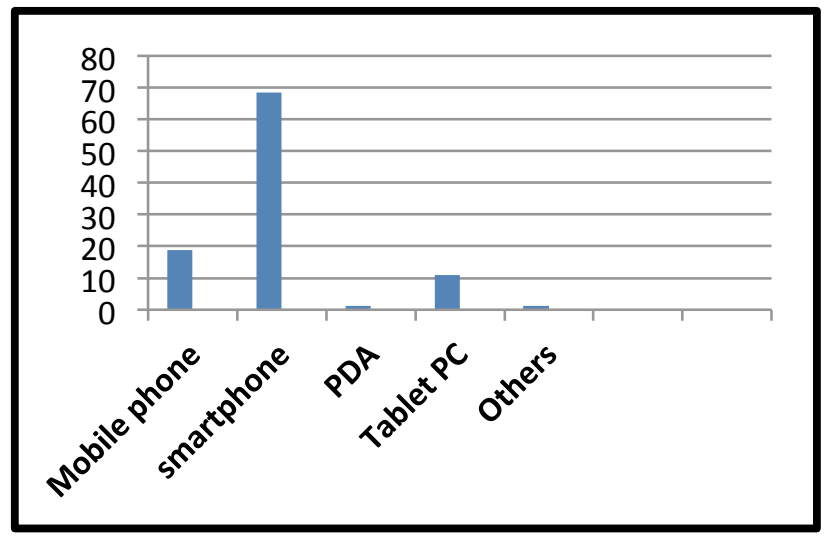

Figure 2. "Availability of Mobile Device"

do you access the internet using your mobile device inside and

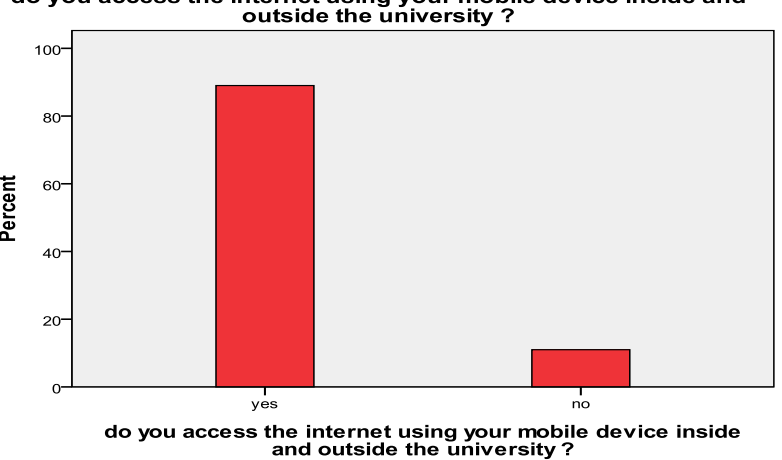

Figure 3. "Internet accessibility using mobile device"

\section{a every day monthly rarely}

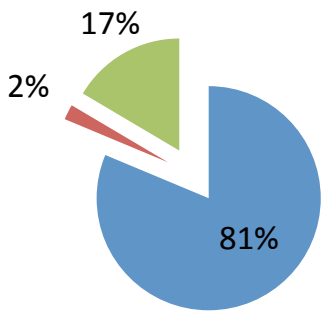

Figure 4. "Times of internet access by mobile device" 


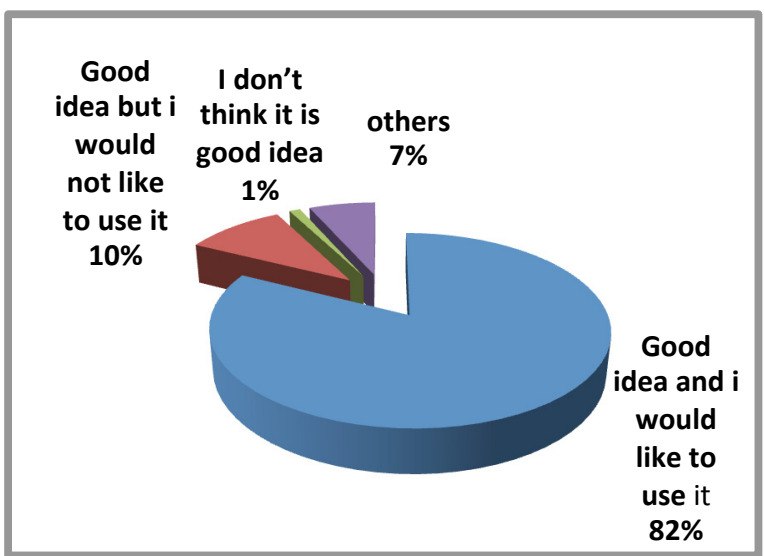

Figure 5. "Students opinions about m-learning"

\section{Students' perceptions towards applying M-learning}

Table 3 contains 7 statements to explore the students' perceptions for applying m-learning services.

The first statement asked respondents "if the mobile device useful to accesses lectures online", the responses mean was $(M=4.0220)$, this indicates that the students "agree". In addition, $47.3 \%$ of respondents agreed that the mobile device useful to access the lectures online, $31.9 \%$ strongly agreed, $15.4 \%$ neutral,2.2\% disagreed and 3.3\% strongly disagreed as shown in Figure 6.

The mean in the second statement was $(M=4.0330)$ this indicates that the students "agree" when they used mobile device will increase the flexibility to learn inside and outside classroom. Figure 7 shows $47.3 \%$ of the respondents agreed, 34.1 strongly agreed, 9.9\% neutral, while $5.5 \%$ disagreed and $3.3 \%$ strongly disagreed.

The results of the third statement $(M=3.9011)$ indicates that the students "agree" with using mobile device in teaching and learning will make the learning process easier and enjoyable. As shown in Figure 8, 51.6\% agreed, $23.1 \%$ strongly agreed, $19.8 \%$ neutral, whereas $3.3 \%$ disagreed, $2.2 \%$ strongly disagreed.

TABLE III

“STUDENTS' PERCEPTIONS ON M-LEARNING"

\begin{tabular}{|l|c|c|c|c|}
\hline \multicolumn{1}{|c|}{ Statement } & N & $\begin{array}{c}\text { Min- } \\
\text { imum }\end{array}$ & $\begin{array}{c}\text { Max- } \\
\text { imum }\end{array}$ & Mean \\
\hline $\begin{array}{l}\text { 1. I think it is useful to access lectures } \\
\text { online using my mobile device. } \\
\text { 2. I believe that using a mobile device } \\
\text { will increase the flexibility to learn } \\
\text { inside and outside the classroom. }\end{array}$ & 91 & 1.00 & 5.00 & 4.0220 \\
\hline $\begin{array}{l}\text { 3. I think implementing and using M- } \\
\text { learning as a part of teaching and } \\
\text { learning process will make the educa- } \\
\text { tional process easier and more enjoya- } \\
\text { ble. }\end{array}$ & 91 & 1.00 & 5.00 & 5.0330 \\
\hline $\begin{array}{l}\text { 4. I think that using M-learning will } \\
\text { help me to get good grades. }\end{array}$ & 91 & 1.00 & 5.00 & 3.9011 \\
\hline $\begin{array}{l}\text { 5. Implementing M-learning will } \\
\text { enable me to have independent learn- } \\
\text { ing. }\end{array}$ & 91 & 2.00 & 5.00 & 3.7692 \\
\hline $\begin{array}{l}\text { 6. I think M-learning will add value } \\
\text { to e-learning. }\end{array}$ & 91 & 2.00 & 5.00 & 4.0110 \\
\hline $\begin{array}{l}\text { 7. I would be interested to learn using } \\
\text { this method in the future. }\end{array}$ & 91 & 1.00 & 5.00 & 3.9780 \\
\hline
\end{tabular}

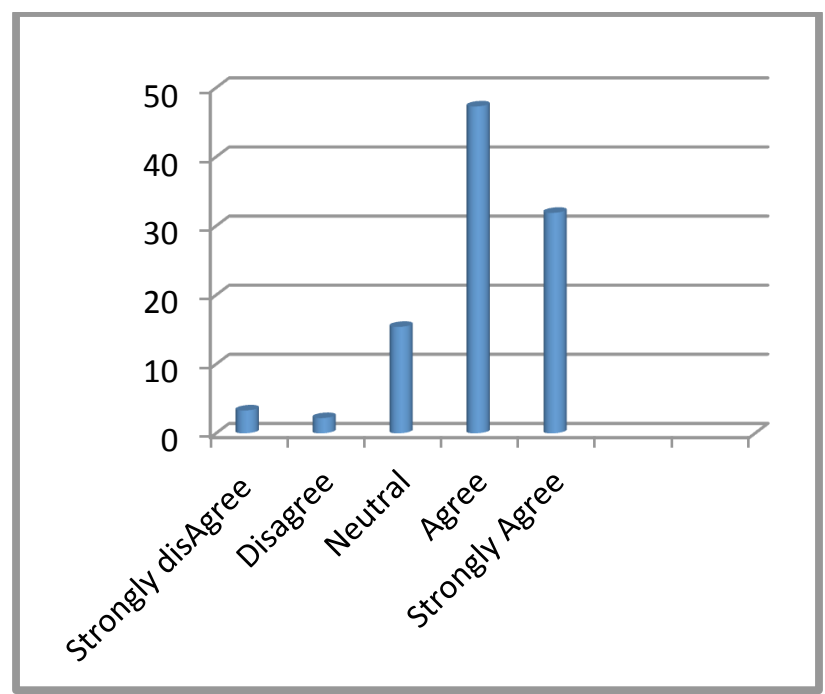

Figure 6. "Useful to access lectures online using mobile device using mobile device".

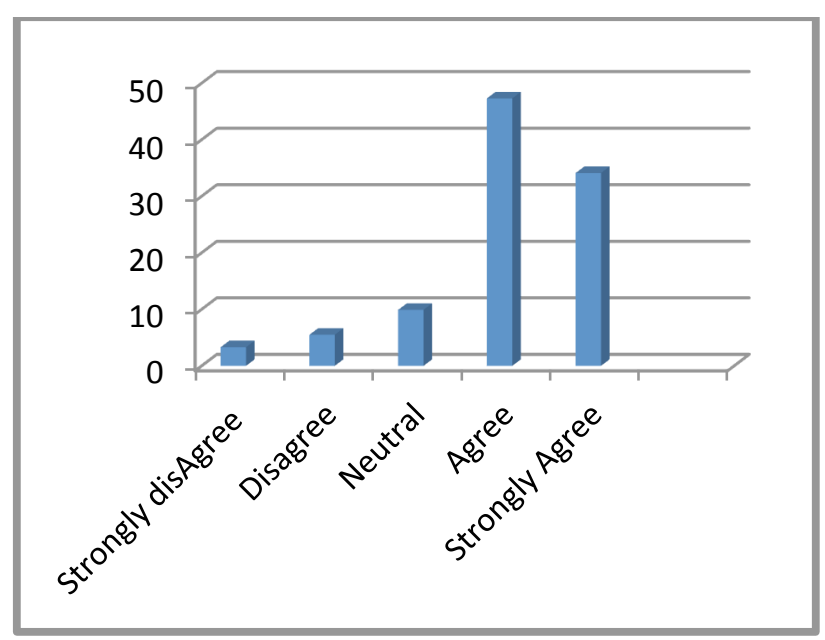

Figure 7. "Flexibility to learn using mobile device"

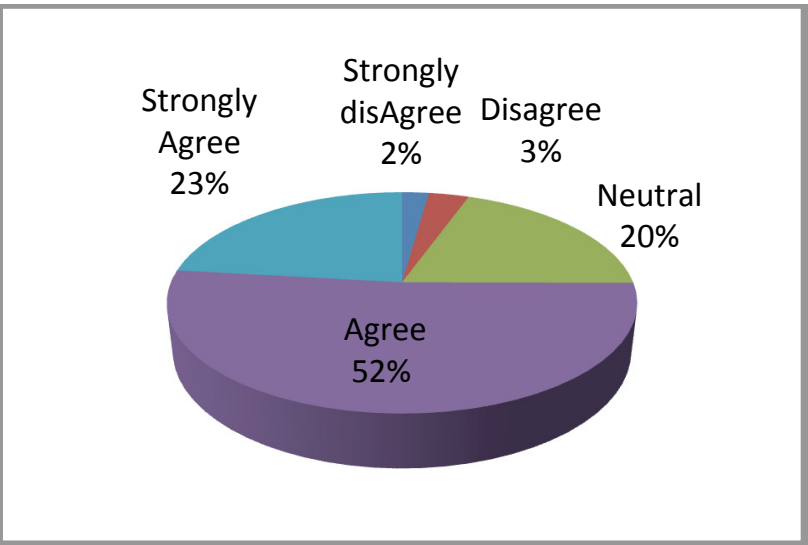

Figure 8. "More easier and enjoyable using mobile device"

In the fourth statement the mean was $(\mathrm{M}=3.4835)$ this indicates the students between "agree" and "neutral" for using m-learning will help them to improve grades. $42.9 \%$ neural, $37.4 \%$ agreed, $11.0 \%$ strongly agreed, $6.6 \%$ disagreed and $2.2 \%$ strongly disagreed as shown in Figure 9.

The next statement asked "If m-learning enable students' independent learning", the responses mean was $(M=3.7692)$ this indicates between "agree" and "neutral". 
As shown in Figure 10 that $51.6 \%$ of respondents agreed, $16.5 \%$ strongly agreed, $24.2 \%$ neutral and $7.7 \%$ disagreed.

In the statement six the responses mean was $(\mathrm{M}=$ 4.0110) this indicates that the students "agree" that mlearning add value to e-learning. Majority of respondents $75.8 \%$ agreed, $15.4 \%$ strongly agreed, $3.3 \%$ neutral and $5.5 \%$ disagreed as shown in Figure 11.

The last statement asked "If the students interested to learn using m-learning in the future", the mean was $(\mathrm{M}=$ 3.9780) this indicates the students agree to use m-learning in the future as learning process. As shown in Figure 12 that $82.4 \%$ of the respondents agreed to use m-learning in the future, $11.0 \%$ strongly agreed and $2.2 \%$ neutral, disagreed and strongly disagreed.

\section{E. Students' expectations of M-learning services.}

The study aims to explore students' expectations on mobile learning services that they would like use through their mobile devices. The study found as shown in Figure 13 that the majority of respondents $83.5 \%$ preferred access learning contents online using their mobile device and $81.3 \%$ for exam results were the highest ranked, followed admission status $75.8 \%$, library service $71.4 \%$, course registration $70.3 \%$, schedule services $67.0 \%$, to collaborate with other students and financial balance $58.2 \%$ and the lowest rank was to collaborate with lecturers $54.9 \%$.

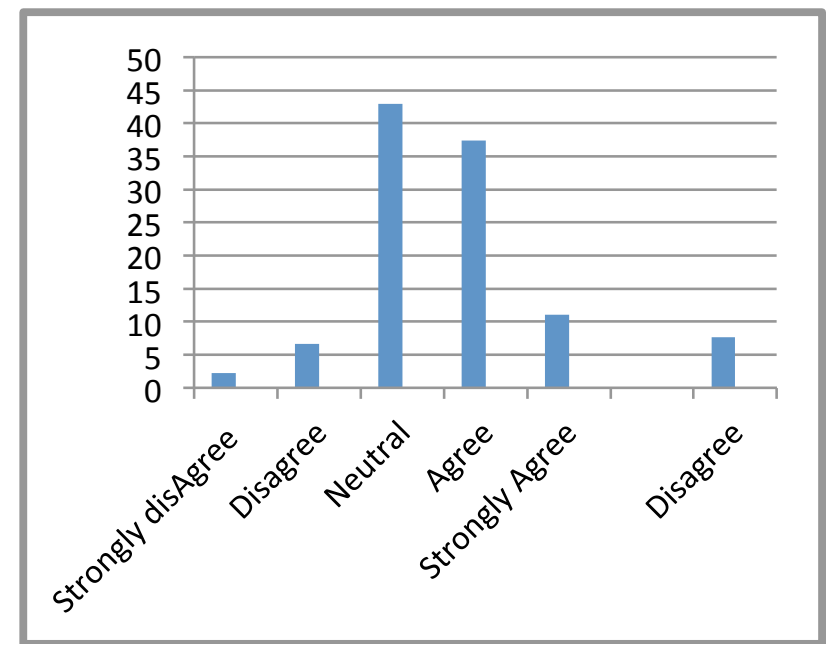

Figure 9. "Improve students' grades using M-learning"

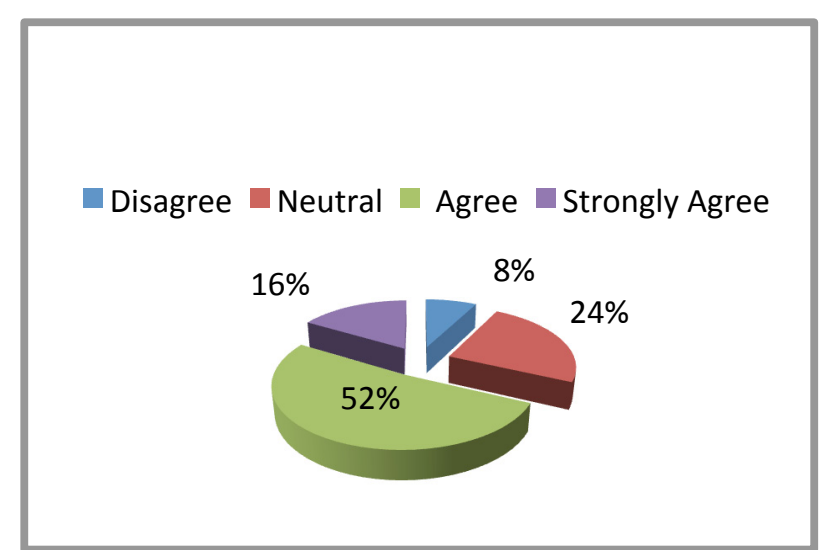

Figure 10. "Learning independent using m-learning"

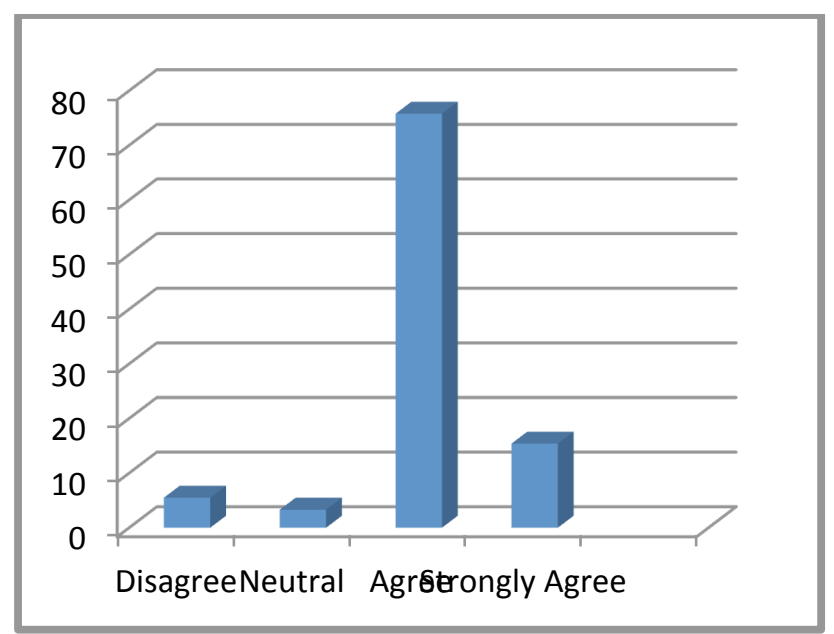

Figure 11. "M-learning add value to e-learning"

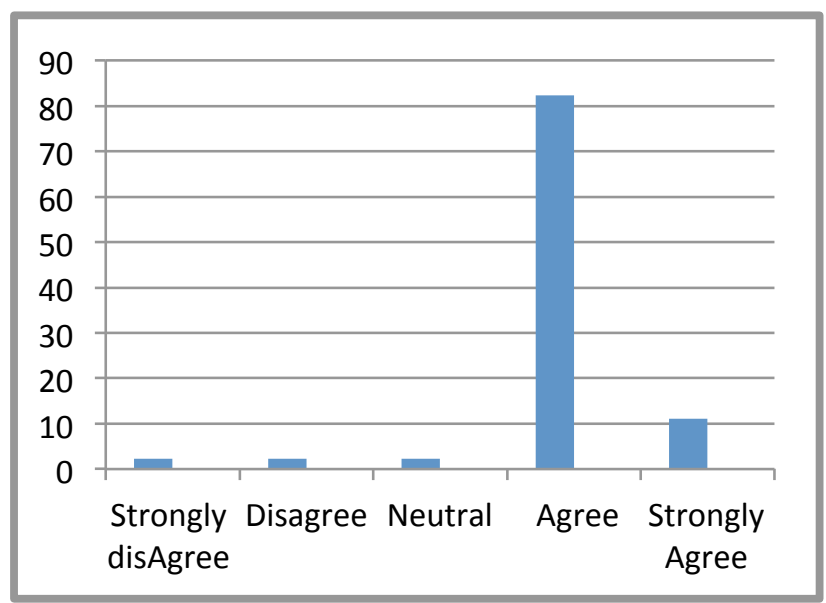

Figure 12. "Use m-learning in the future"

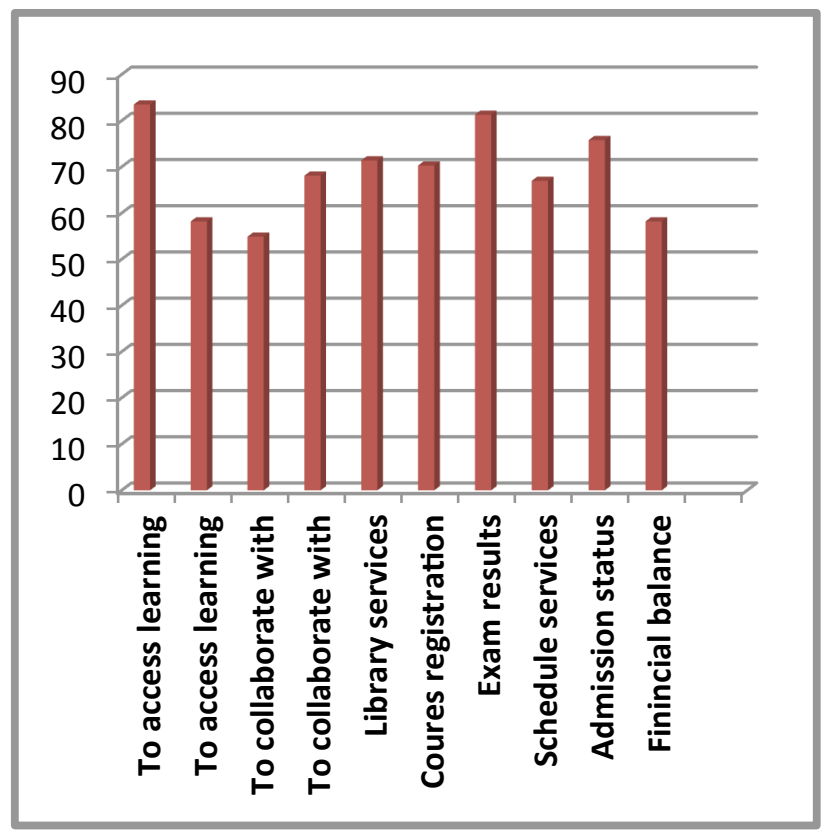

Figure 13. "M-learning services" 


\section{CONCLUSION}

This study sought to explore students' perceptions of the application of m-learning and to investigate the students' expectations of m-learning services through their studies. Based on the results, the majority of students have positive perceptions on the use of m-learning. The results of this study indicate that the students may access to lectures online by using mobile devices more easily and useful. The results also indicated that mobile learning will help to increase flexibility of learning inside and outside classroom because the students' can access to learning materials anywhere and anytime. As in this study, most of the students expect that the use of m-learning will help them to improve academic achievement and enable them to independent learning.

The results also indicated that students perceive that $\mathrm{m}$ learning will play an important role of in learning and will add value to e-learning in the future. The results showed that the majority of students would like to use this technology in the future. Finally, the study found highly ranked m-learning services the expected to be used by students include online access to learning materials and administrative services such as retrieving exam results and library services etc.

However, the use of mobile wireless technologies will become the choice for the students in higher education environment in the future; there is still need to further investigate the critical success factors that influence mlearning acceptance among students.

\section{REFERENCES}

[1] Ally, M., \& Prieto-Blázquez, J. (2014). What is the future of mobile learning in education?. RUSC. Universities and Knowledge Society Journal, 11(1), 142-151. http://dx.doi.org/10.7238/rusc .v11i1.2033

[2] Alzaza, N. S., \& Yaakub, A. R. (2011). Students' awareness and requirements of mobile learning services in the higher education environment. American Journal of Economics and Business Administration, 3(1), 95. http://dx.doi.org/10.3844/ajebasp.2011. $\underline{95.100}$

[3] Andrew Litchfield, Laurel Evelyn Dyson and Elaine Lawrence, Agnieszka Zmijewska "Directions for M-Learning research to enhance active leraning," in Ascilite Singapore 2007.

[4] Attewell, J. (2005). Mobile Technologies and Learning: A Technology Update and m-Learning Project Summary. Technology Enhanced Learning Research Centre. London, UK: The Learning and Skills Development Agency. Available at: http://www.mlearning.org/archive/docs/The $\% 20 \mathrm{~m}$-learning $\% 20$ project $\%$ 20-\%20technology $\% 20$ update $\% 20$ and $\% 20$ project $\% 20$ sum mary.pdf

[5] Botzer, G. and Yerushalmy, M. (2007). Mobile Application for Mobile Learning. In Proceedings of the International Conference on Cognition and Exploratory Learning in the Digital Age (CELDA), September 7-9, Algarve, Portugal.

[6] Cisco. (2012). University Embraces Bring-Your-Own-Device with Wireless Network [Online]. http://www.cisco.com/en/US/ prod/collateral/wireless/C36-698193-00 University Embr aces Bring-Your-Own-Device.pdf

[7] Chen, C. M. , \& Chung, C. J. (2008). Personalized mobile English vocabulary learning system based on item response theory and learning memory cycle. Computers \& Education, 51(2), 624-645. $\mathrm{http}: / / \mathrm{dx}$. doi. org/10. 1016/j. compedu. 2007. 06.011 http://dx.doi.org/10.1016/j.compedu.2007.06.011

[8] Fernandez, V., Simo, P., \& Sallan, J. M. (2009). Podcasting: A new technological tool to facilitate good practice in higher education. Computers \& Education, 53(2), 385-392. http://dx.doi.org/10.1016/j.compedu.2009.02.014
[9] Haag, J. (2011, January). From elearning to mlearning: the effectiveness of mobile course delivery. In The Interservice/Industrv Training, Simulation \& Education Conference (I/ITSEC) (Vol. 2011, No. 1). National Training Systems Association.

[10] J. Hoffmann and N. Miner, Tailored Learning: Designing the Bled that Fits, Massachusetts: American Society for Training and Development, 2009, pp. 182.

[11] Hussin, S. , Manap, M. , Amir, Z. , \& Krish, P. (2012). Mobile Learning Readiness among Malaysian Students at Higher Learning Institutes. Asian Social Science, 8(12), 276-283. http://dx.doi.org/10.5539/ass.v8n12p276

[12] Korucu, A. T., \& Alkan, A. (2011). Differences between mlearning (mobile learning) and e-learning, basic terminology and usage of m-learning in education. Procedia-Social and Behavioral Sciences, 15, 1925-1930. http://dx.doi.org/10.1016/j.sbspro.2011. 04.029

[13] Laouris, Y. and Eteokleous, N. (2005). We need an Educationally Relevant Definition of Mobile Learning. In Proceedings of the 4th World Conference on mLearning. October 25-28, Cape Town, South Africa. Available at: < http://www.mlearn.org.za/CD/ papers/Laouris \%20and\%20Eteokleous.pdf $>$

[14] Liu, Y., Li, H. , \& Carlsson, C. (2010). Factors driving the adoption of m-learning: an empirical study. Computers \& Education, 55(3), 1211-1219. http://dx.doi.org/10.1016/j.compedu.2010. $\underline{05.018}$

[15] Mcconatha, D., Praul, M., \& Lynch, M. J. (2008). Mobile Learning in Higher Education: An Empirical Assessment of a New Educational Tool. Turkish Online Journal of Educational Technology, 7(3).

[16] Park, Y. (2011). A Pedagogical Framework for Mobile Learning: Categorizing Educational Applications of Mobile Technologies into Four Types. International Review of Research in Open \& Distance Learning, 12(2).

[17] Traxler, J. (2007). Defining, Discussing and Evaluating Mobile Learning: The moving finger writes and having writ.... The International Review of Research in Open and Distance Learning, 8(2). Available at: < http://www.irrodl.org/index.php/irrodl/ article/viewarticle/346/875 >.

[18] Trifonova, A. N. N. A., Georgieva, E. V. G. E. N. I. Y. A., \& Ronchetti, M. A. R. C. O. (2006). Determining students' readiness for mobile learning. InProceedings of the 5th WSEAS International Conference on E-ACTIVITIES(pp. 20-22).

[19] UNESCO, Policy Guidelines for Mobile Learning, 2011.

[20] Virvou, M. , \& Alepis, E. (2005). Mobile educational features in authoring tools for personalised tutoring. Computers \& Education, 44(1), 53-68. http://dx.doi.org/10.1016/j.compedu.2003.12.020

[21] Wang, Y. S. ,Wu, M. C. , \&Wang, H. Y. (2009). Investigating the determinants and age and gender differences in the acceptance of mobile learning. British Journal of Educational Technology, 40(1), 92-118. http://dx.doi.org/10.1111/j.1467-8535.2007.00809.x

[22] J. Wishart and D. Green. (2010, June 29). Identifying Emerging Issues in Mobile Learning in Higher and Further Education [Online]. http://www.jiscdigitalmedia.ac.uk/blog/entry/ resources-for-mobile-learning.

[23] Yin, C., David, B., \& Chalon, R. (2009, August). Use your mobile computing devices to learn-Contextual mobile learning system design and case studies. InComputer Science and Information Technology, 2009. ICCSIT 2009. 2nd IEEE International Conference on (pp. 440-444). IEEE.

[24] Yusup, Y. (2014). Preliminary study on teachers' use of the iPad in bachelor of education program at a private university in Malaysia. TechTrends, 58(2), 14-19. http://dx.doi.org/10.1007/s11528014-0732-y

\section{AUTHORS}

Mohammed Amin Almaiah and Masita@ Masila Abdul Jalil are with the School of Informatics and Applied Mathematics, University Malaysia Terengganu, Terengganu, Malaysia (mohammad7ups@yahoo.com masita@umt.edu.my).

Submitted 14 June 2014. Published as resubmitted by the authors 14 October 2014. 